\title{
THE ACCOUNTING TREATMENT OF THE VALUE DIFFERENCES RESULTED FROM THE EVALUATION OF COMPANIES INVOLVED IN THE MERGER PROCESS
}

\author{
Deju Mihai \\ "Vasile Alecsandri" University of Bacău \\ mihai.deju@ub.ro
}

\begin{abstract}
The financial accounting aspects concerning the reorganisation of companies by merger operations are of special interest, both for the specialists in the theory field and for those in the accounting practice taking into account the permanent changes and adaptions of the Romanian regulations to the European and international accounting framework. This article aims to approach the aspects concerning the accounting treatment of the value differences created as a result of the evaluation of the companies involved in merger operations.
\end{abstract}

\section{Keywords}

merger; reorganisation; evaluation; accounting

\section{JEL Classification}

M41

The merger is one of that legal means that allow the reorganisation of companies in order to meet the need for their expansion. In addition, from the point of view of economic management, it contributes both to the harmonisation and rationalisation of the production means, and to the improvement of the technology and ability to accomplish certain objectives (the funding of research activities, production specialization etc.).

The merger is decided by each company with the observance of the terms in the articles of incorporation. Thus, in accordance with the decision of the general meeting of shareholders of each company involved in the operation, their administrators will draw up a merger project that will comprise information on the conditions of the merger ${ }^{1}$, namely: data relating to the identification of all the companies involved in the merger; the dates when there were approved the financial statements of participating companies, which have been used for substantiation and conditions of the merger; the date from which the allocated shares give holders the right to share in profits and any special conditions affecting that entitlement; the exchange rate of shares or social parts and the amount of any cash payment; the amount of the premium for merger etc.

The managers of the companies participating in the merger should produce a detailed written report explaining the draft terms of merger and clarify its legal and economic foundation, in particular with regard to the exchange rate of shares as well as any special difficulties encountered in carrying out the evaluation of the assets of the

\footnotetext{
${ }^{1}$ Law no. 31/1990 on commercial companies, republished in Monitorul Oficial no. 1066/2004, with further completions and changes, art. 241
} 
companies subject to reorganization through merger, in order to determine the net merger contribution ${ }^{2}$, respectively the value with which they participate in the merger. The determination of the net merger contribution of a merger can be done on the basis of the net asset value determined on the basis of accounting value of balance sheet items or based on values established through an assessment report drawn up for this purpose by authorised assessors.

The accounting treatment of the differences arising in the evaluation of the patrimony of the companies involved in the reorganisation by merger operations is an issue of interest to specialists in the field of financial accounting and which will be subject to the detailed presentation within this article.

The amount of net merger contribution, established by one of the methods mentioned, will form the basis for the determination of the exchange ratio of shares of companies participating in the merger operation.

The accounting net asset value equals the net merger contribution from the merger only if at the basis of the accounting of the reorganisation operations through merger is the net asset method, in which case the items of the balance sheet of the companies involved in the merger are taken into account at the value at which they are recorded in the accounting. ${ }^{3}$ In all other cases, where the two values are not equal, the difference between the amount of the merger contribution and the net accounting value of the company being acquired is recognised as a plus value or minus value from the merger, whose accounting treatment differs from the two companies entered into a merger.

Thus, in the accounting of the acquiring company/the newly established company, the difference between the amount of net merger contribution for the merger and the net accounting asset value of the company being acquired is recognised according to the corresponding balance sheet items or on the account of "goodwill"- in case of the unallocated differences, while at the company being acquired the respective difference represents gain or loss in the merger ${ }^{4}$.

The accounting treatment in the acquiring company, of the differences arising out of the evaluation of the company being acquired as a result of the merger, as mentioned above, is determined by the possibility of identifying differences in evaluation as belonging, or not, to certain items on the balance sheet.

Thus, in the case when there are used evaluation methods that enable the identification of differences resulting from the evaluation of the net merger contribution of the company being acquired, these differences will be recognised in the accounts of the acquiring company, at the balance sheet items to which they correspond.

In cases where, in order to assess the net merger contribution, there are used methods for the overall evaluation (stock market method, a method based on results, etc.), and the resulting difference between the accounting net assets of the company being acquired, cannot be allocated to certain identifiable elements on the balance sheet, it will be recognized in the acquiring company's accounts as goodwill.

At the acquiring company, the differences arising out of the evaluation of its own balance sheet items are not recorded in the accounts; they are used only in the determination of the exchange ratio.

To illustrate appropriately the accounting treatment applied to the differences arising out of the evaluation of the companies involved in the reorganisation process, there

\footnotetext{
${ }^{2}$ OMFP no. 897/2015 for the approval of methdological norms concerning the reflection in accounting of the main operations of fusion,division and liquidation of companies as well as of withdrawal or exclusion of certain associates within the companies, pct.15 b.

${ }^{3}$ Idem, pct. 15 a.

${ }^{4}$ Idem, pct.20 a,b.
} 
will be presented, with reference to the companies involved in the merger, a hypothetical example:

1. Assuming that the net merger contribution of the company being acquired, determined both according to the accounting value of balance sheet items and the value resulting from the evaluation occasioned by the merger is presented like this:

\begin{tabular}{|c|c|c|c|c|c|}
\hline \multirow[b]{2}{*}{$\begin{array}{l}\text { The balance sheet items afferent } \\
\text { to the net merger contribution of } \\
\text { the acquired company }\end{array}$} & \multirow[b]{2}{*}{$\begin{array}{l}\text { To } \\
\text { accounting } \\
\text { value }\end{array}$} & \multicolumn{2}{|c|}{ To evaluated value } & \multicolumn{2}{|c|}{ Differences } \\
\hline & & $\begin{array}{l}\text { a) the case } \\
\text { of } \\
\text { identifiable } \\
\text { differences }^{*}\end{array}$ & $\begin{array}{l}\text { b) the case } \\
\text { of } \\
\text { unallocated } \\
\text { differences } \\
* *\end{array}$ & $\begin{array}{l}\text { Identifiable } \\
\text { col.2-col.1 }\end{array}$ & $\begin{array}{l}\text { Unallocated } \\
\text { col.3-col.1 }\end{array}$ \\
\hline 0 & 1 & 2 & 3 & 4 & 5 \\
\hline \multicolumn{6}{|l|}{$\begin{array}{l}\text { A) The case of positive } \\
\text { difference }\end{array}$} \\
\hline $\begin{array}{ll}\text { - } & \text { Total assets } \\
\text { - } & \text { Unallocated differences } \\
\end{array}$ & $\begin{array}{r}1200 \\
-\end{array}$ & $\begin{array}{r}1600 \\
-\end{array}$ & $\begin{array}{r}1200 \\
400 \\
\end{array}$ & $\begin{array}{r}+400 \\
- \\
\end{array}$ & 400 \\
\hline - $\quad$ Debts & 500 & 500 & 500 & - & - \\
\hline $\begin{array}{ll}\text { - } & \begin{array}{l}\text { Net merger contribution } \\
\text { (equity) }\end{array} \\
\end{array}$ & 700 & 1100 & 1100 & +400 & +400 \\
\hline \multicolumn{6}{|l|}{$\begin{array}{l}\text { B) The case of negative } \\
\text { difference }\end{array}$} \\
\hline $\begin{array}{ll}- & \text { Total assets } \\
\text { - } & \text { Unallocated differences } \\
\end{array}$ & $\begin{array}{r}1200 \\
-\end{array}$ & $\begin{array}{r}950 \\
- \\
\end{array}$ & $\begin{array}{r}1200 \\
-250 \\
\end{array}$ & $\begin{array}{r}-250 \\
- \\
\end{array}$ & $\begin{array}{r}- \\
-250 \\
\end{array}$ \\
\hline - $\quad$ Debts & 500 & 500 & 500 & - & - \\
\hline $\begin{array}{l}\text { - Net merger contribution } \\
\text { (equity) }\end{array}$ & 700 & 450 & 450 & -250 & -250 \\
\hline
\end{tabular}

Note: * the differences are identifiable as a result of the individual evaluation of the balance sheet items of the company being acquired.

** the differences resulted from the evaluation of the company being acquired cannot be allocated as a result of the global evaluation of the respective patrimony.

2. The accounting treatment at the acquiring company of the differences resulted from the evaluation of the company being acquired with the occasion of the merger:

A) the case of positive differences:

a) the registration of the capital growth and of the merger premium:

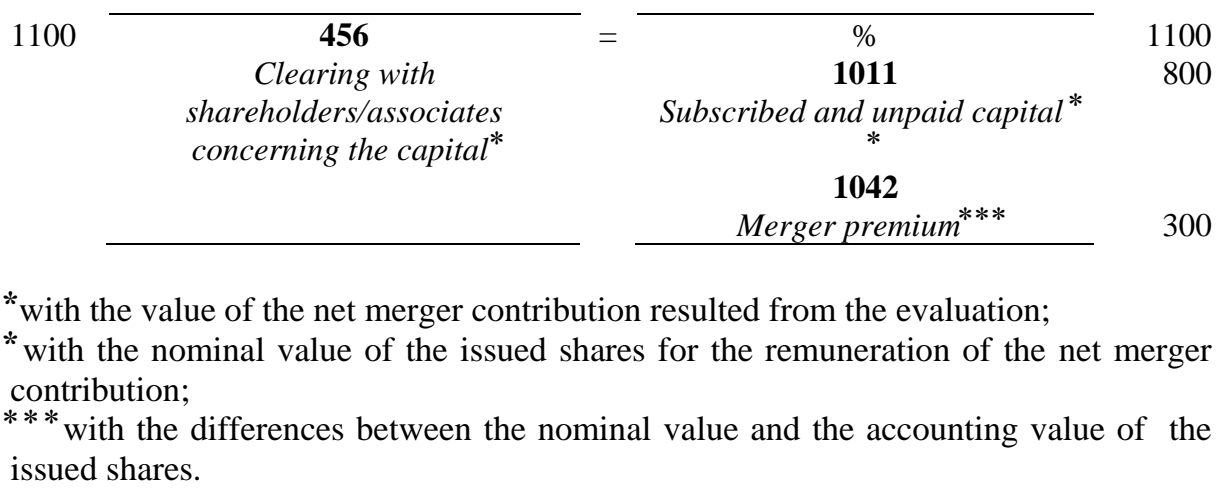


b) the registration of the transfer of assets and liabilities:

b1) the case of positive difference allocated to identifiable asset items:

1600

1600

Balance asset accounts

(with evaluated value)

\begin{tabular}{c}
\hline$\%$ \\
Debts accounts \\
$\mathbf{4 5 6}$ \\
Clearing with \\
shareholders/associates \\
concerning the capital \\
(with the value of the merger \\
net contribution)
\end{tabular}

400

\section{1}

Positive commercial fund

(with positive difference between the merger contribution value and the net asset accounting value)
Debts accounts (with accounting value)

\section{6}

Clearing with shareholders/ associates concerning the capital (with the value of the net merger contribution)

B) the case of negative difference

a) the registration of capital growth and the merger premium:

450

$\mathbf{4 5 6}$
Clearing with
shareholders/associates
concerning the capital (with
the value of the net merger
contribution)

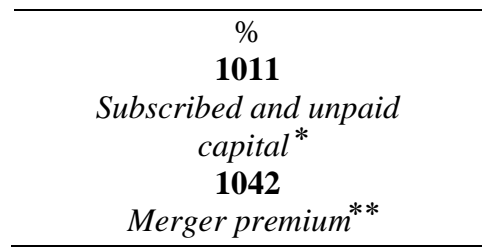

* with the nominal value of the shares issued for the remuneration of the net merger contribution;

* with the difference between the nominal value and the mathematical-accounting value of the issued shares.

b) the registration of the assets and debts items taken from the company being acquired:

b1) the case of the negative difference allocated to some identifiable assets items:

950

950
Accounts of assets items

(with evaluated value)

\section{$=$}

Debts accounts

(with accounting value)

456

Clearing with shareholders/

associates concerning the

capital (with the value of the 
b2) the case of the unallocated negative difference:

$$
\text { merger net contribution) }
$$

1200

1200

$\%$
Accounts of the balance sheet
assets items
(with accounting value)

(with accounting value)

$\%$
Debts accounts
(with accounting value)
Clearing with shareholders/
associates concerning the
capital (with the value of the
net merger contribution)
$\mathbf{2 0 7 . 5}$
Negative commercial fund (with
negative difference between the
net merger contribution value
and the net asset accounting
value)

3. The accounting treatment at the company being acquired of the differences from the evaluation within the merger:

The differences resulted from the evaluation of the company being acquired, occasioned by the merger, are recognised in the accounting of the company being acquired as profit - if they are positive or as loss - if they are negative.

In accordance with the valid accounting regulations ${ }^{5}$, at the company being acquired, the differences between the two values are recognised, by means of the accounts 6583 „Expenses for the sold assets and other capital operations" and 7583 ,,Income from the selling of assets and other capital operations", in the account 121 ,Profit or loss” as a result of the merger, as follows:

a) the case of pluses or minuses of value resulting from the evaluation of the company being acquired, afferent to some identifiable items on the balance sheet.

The pluses of value resulting from the evaluation in the merger, at the company being acquired, there are recognised as gains from the merger through the accounts 7583 "Income from the selling of assets and other capital operations" and 6583 "Expenses concerning the deferred assets and other capital operations", once the registration of the transfer of the assets of the company being acquired to the acquiring company to the appraised value as a result of the merger, as well as the discharge of management with accounting value of the transferred assets.

a1) the case of positive differences afferent to some identifiable balance sheet items:

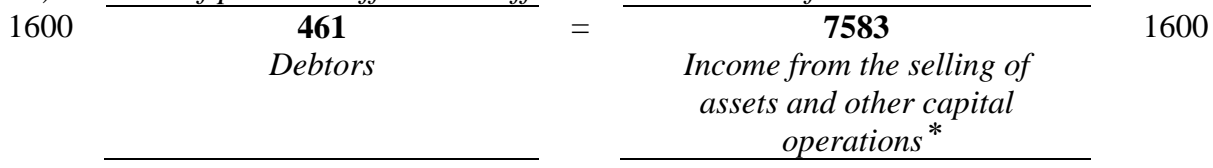

\footnotetext{
${ }^{5}$ OMFP nr. 897/2015 for the approval of methdological norms concerning the reflection in accounting of the main operations of fusion,division and liquidation of companies as well as of withdrawal or exclusion of certain associates within the companies.
} 
* with evaluated value of identifiable elements, of assets, which represent merger contribution

1200

\begin{tabular}{c}
$\mathbf{6 5 8 3}$ \\
$\begin{array}{c}\text { Expenses from the selling of } \\
\text { assets and other capital } \\
\text { operations }\end{array}$ \\
\hline
\end{tabular}

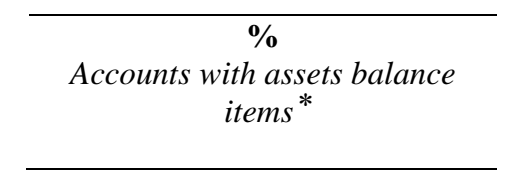

*with the accounting value of assets items that represent merger contribution

$1600 \begin{gathered}\mathbf{7 5 8 3} \\ \begin{array}{c}\text { Income from the selling of } \\ \text { assets and other capital } \\ \text { operations }\end{array}\end{gathered}$

Following these operations, the balance account 121 „Profit or loss” reflects the positive differences resulting from the evaluation of the company being acquired, recognized as gain (profit) from the merger.

a2) in the case of negative differences, afferent to some identifiable items on the balance sheet.

The minuses in value resulting from the evaluation in the merger of the company being acquired are recorded in the accounts as losses from the merger through the accounts of revenue and expenditure. Therefore in the account 7583 account "Income from the selling of assets and other capital operations", there will be reflected the value resulting from the evaluation (lower than the accounting value), and in the account 6583 "Expenses from the selling of assets and other capital operations" will be reflected in the accounting values of the transferred assets.

950

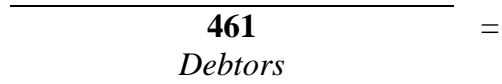

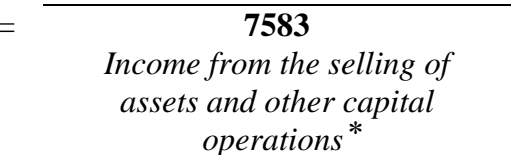
operations *

Income from the selling of

* with the evaluated value of the assets $i t e m s$ that represents net merger contribution

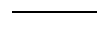
1200

$\mathbf{6 5 8 3}$
Expenses from the selling of
assets and other capital
operations
$=$
Expenses from the selling of operations
* with the accounting value of identifiable assets items that represent merger contribution

\begin{tabular}{|c|c|c|c|}
\hline 950 & $\begin{array}{c}\mathbf{7 5 8 3} \\
\text { Income from the selling of } \\
\text { assets and other capital } \\
\text { operations }\end{array}$ & $=$ & $\begin{array}{c}\mathbf{1 2 1} \\
\text { Profit or loss }\end{array}$ \\
\hline 1200 & 121 & $=$ & 6583 \\
\hline
\end{tabular}


Deju

\begin{tabular}{c} 
Profit or loss \\
$\begin{array}{c}\text { Expenses from the selling of } \\
\text { assets and other capital } \\
\text { operations }\end{array}$ \\
\hline
\end{tabular}

The account balance "Profit or loss" will reflect the negative differences resulting from the evaluation of the company being acquired, recognized as a loss from the merger.

b) the case of pluses or minuses of value, resulting from the evaluation of the company being acquired, that cannot be allocated to certain identifiable elements on the balance sheet.

In the case of pluses or minuses of value that are not allocated to some identifiable assets arising as global difference between the value of the net merger contribution obtained in the evaluation within the merger and net asset accounting value, they will be reflected through revenue and expenditure accounts, in the account 121 "Profit or Loss" as a gain or loss from the merger, and also as the difference between the value of the net merger contribution and the net asset accounting value of the company being acquired is positive or negative, thus:

b1) the case of the unallocated positive difference

1600

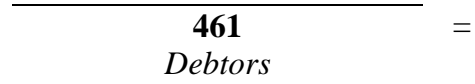

Debtors

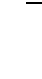

Income from the selling of assets and other capital operations*

* with the accounting value of the assets balance elements of the company being acquired, which represents net merger contribution (1200 lei) and with the value of the positive difference between the value of the net merger contribution and the value of the accounting net asset of the company being acquired $(1100-700=400$ lei)

1200

$\mathbf{6 5 8 3}$
$\begin{gathered}\text { Expenses from the selling of } \\ \text { assets and other capital } \\ \text { operations }\end{gathered}$

$=$

Accounts with assets balance elements

${ }^{*}$ with the accounting value of assets of the company being acquired that represents net merger contribution

1600

\begin{tabular}{c}
$\mathbf{7 5 8 3}$ \\
$\frac{\begin{array}{c}\text { Income from the selling of } \\
\text { assets and other capital } \\
\text { operations }\end{array}}{}=$ \\
\hline $\mathbf{1 2 1}$ \\
Profit or loss
\end{tabular}

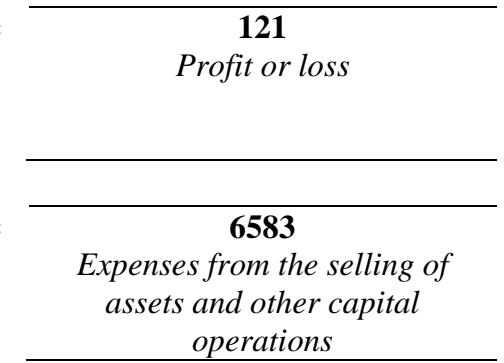

1200

Profit or los operations

The account balance 121 "Profit or loss" will reflect the positive difference between the value of the net merger contribution resulted from evaluation within the merger (1100 lei) and the net asset accounting value of the company being acquired (700 lei).

b2) the case of the unallocated negative difference:

$\overline{461}=$




\begin{tabular}{cc}
\hline Debtors & $\begin{array}{c}\text { Income from the selling of assets } \\
\text { and other capital operations }\end{array}$ \\
\hline
\end{tabular}

* with the accounting value of the assets of the company being acquired, constituting the net merger contribution (1200 lei) and the value of the negative difference between the value of the net merger contribution and net asset value of the company being acquired $(450-700=-250$ lei $)$.

$\mathbf{6 5 8 3}$
$\begin{gathered}\text { Expenses from the selling of } \\ \text { assets and other capital } \\ \text { operations }\end{gathered}$

$\%$
Accounts with assets balance
elements

1200 the net merger contribution

950

\begin{tabular}{c}
\hline $\mathbf{7 5 8 3}$ \\
$\begin{array}{c}\text { Income from the selling of } \\
\text { assets and other capital } \\
\text { operations }\end{array}$ \\
\hline $\mathbf{1 2 1}$ \\
Profit or loss \\
\hline
\end{tabular}

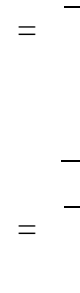

1200

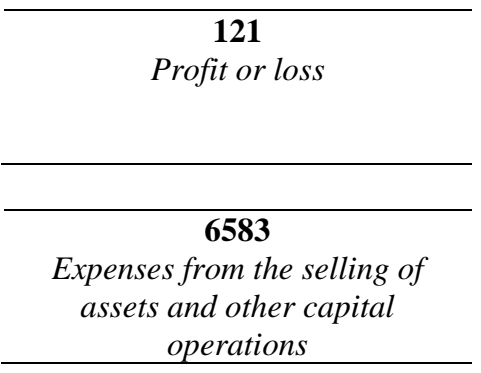

The account balance 121 "Profit or loss" will reflect the negative difference between the value of the net merger contribution (450 lei) and net asset accounting value (700 lei) recognised as a loss from the merger.

\section{Conclusions}

The accounting treatment of the plus values or minus values resulting from the evaluation of the elements on the balance sheet, on the occasion of the merger, raises issues of accounting reasoning. They must be analysed in light of the possibility of their allocation, of certain identifiable balance sheet elements or as representing overall differences resulting from the assessment arising from the merger through the use of some specific methods (stock exchange method, method of profitability, etc.) which cannot be assigned to certain identifiable elements on the balance sheet.

The differences from evaluation of the acquiring company shall not be recognised in its accounting as they are used only for the determination of the exchange ratio, while differences related to the evaluation the company being acquired have a different treatment, thus:

a) the differences arising out of the evaluation of the company being acquired in connection with the merger, are recognised in the accounts of the acquiring company to the balance sheet elements to which they belong, or as goodwill, in the case of unallocated differences;

b) the differences resulting from the evaluation of the balance sheet elements in connection with the merger, at the company being acquired they are recognized as gain or loss through income and expenditure accounts.

The specialists in financial accounting, based on this reasoning, will have to apply the appropriate procedures for reflection in accounting of the operations entailed in the merger of the companies. 


\section{References}

Deju, M. (2013), Contabilitate aprofundată - curs universitar, Bacău, Editura Alma Mater.

Accounting Law $n r$. 82/1991, republished in Monitorul Oficial nr.454/2008, with further amendments and completions.

Company Law nr. 31/1990, republished in Monitorul Oficial, Partea I, nr. 1066 din 17 November 2004, with further amendments and completions.

Order nr. 1802 from 29 December 2014, for the approval of Accounting Regulations on annual individual financial statements and annual consolidated financial statements published in Monitorul Oficial nr. 963 din 30 December 2014, with further amendments and completions.

OMFP nr.1286/ from $1^{\text {st }}$ October 2012, for the approval of Accounting Regulations in accordance with International Standards of financial report, for commercial companies whose real-estate value are admitted on a regulated market, published in Monitorul Oficial nr. 687 din 4 October 2012, with further amendments and completions.

OMFP nr. 897/2015 for the approval of Methodological Norms concerning the recording in accounting of the main operations of merger, division, dissolution and close-out of companies, as well as the withdrawal or exclusion of some associates from the companies, with further amendments and completions. 